\title{
Runggu or local wisdom-based conflict resolution: The role of the Pengituai Kuta
}

\section{Runggu atau resolusi konflik berbasis kearifan lokal: Peran Pengituai Kuta}

\author{
Toba Sastrawan Manik* \& Suharno
}

Department of Pancasila and Civic Education, Graduate Program, Universitas Negeri Yogyakarta Address: Jalan Colombo 1, Caturtunggal, Sleman, Special Region of Yogyakarta 55281

E-mail: tobasastrawanmanik@gmail.com* \& suharno@uny.ac.id

Article History: Received 6 January 2020; Accepted 2 November 2020; Published Online 22 December 2020

\begin{abstract}
Conflict resolution is needed by society, especially in Indonesia, which has a diverse culture; it is inherent in the culture. Conflict resolution based on local wisdom is needed to create peace in society because it always strives to produce decisions that are win-win solutions. This research examines the importance and role of local wisdom as a form of conflict resolution in society and examines the role of the Pengituai Kuta in Pakpak culture as a conflict resolution method. This research is qualitative research with a case study approach conducted in Matanari Hamlet, Ujung Teran Village, Dairi Regency, North Sumatra. The data collection techniques used were semi-structured interviews, observation, and literature study. The subject of information in this study consisted of three people, namely one member of Pengituai Kuta Matanari (JM) and the Head of Matanari Hamlet (PP), and Cultural Practitioner or Humanist Pakpak (LB). According to Miles and Huberman's model, the data is processed, which includes the collection, reduction, presentation, and conclusion. This finding shows that the Pengituai Kuta has an essential and influential role in resolving horizontal conflicts in Matanari Hamlet. The local wisdom of the Indonesian people already has conflict resolution systems and methods. In Pakpak culture, Pengituai Kuta refers to representatives of community leaders who are considered experienced and exemplary. Every conflict is resolved by deliberation-consensus (runggu) in an open, egalitarian, and full of brotherhood.
\end{abstract}

Keywords: conflict resolution; local wisdom; runggu; Pakpak Tribe

\begin{abstract}
Abstrak
Resolusi konflik diperlukan oleh masyarakat, khususnya di Indonesia yang memiliki budaya yang beragam; hal itu melekat dalam budaya. Resolusi konflik berbasis kearifan lokal diperlukan untuk menciptakan perdamaian di masyarakat karena selalu berupaya untuk menghasilkan keputusan yang bersifat win-win solution. Penelitian ini mengkaji pentingnya dan peran kearifan lokal sebagai bentuk penyelesaian konflik di masyarakat. Artikel ini meneliti tentang peran Pengituai Kuta dalam budaya Pakpak sebagai metode resolusi konflik. Penelitian ini merupakan penelitian kualitatif dengan pendekatan studi kasus yang dilaksanakan di Dusun Matanari, Desa Ujung Teran, Kabupaten Dairi, Sumatera Utara. Teknik pengumpulan data yang digunakan adalah wawancara semi terstruktur, observasi, dan studi pustaka. Subjek informasi dalam penelitian ini berjumlah tiga orang yaitu satu orang anggota Pengituai Kuta Matanari (JM) dan Kepala Dusun Matanari (PP), dan Budayawan Pakpak (LB). Menurut model Miles dan Huberman data diolah dengan meliputi pengumpulan, reduksi, penyajian, dan penarikan kesimpulan. Temuan ini ialah Pengituai Kuta memiliki peran penting dan berpengaruh dalam menyelesaikan konflik horizontal di Dusun Matanari. Kearifan lokal masyarakat Indonesia sudah memiliki sistem dan metode penyelesaian konflik. Dalam budaya Pakpak, istilah Pengituai Kuta merujuk pada perwakilan tokoh masyarakat yang dianggap berpengalaman dan memiliki keteladanan. Setiap konflik diselesaikan dengan musyawarah-mufakat (runggu) secara terbuka, egaliter, dan penuh rasa persaudaraan.
\end{abstract}

Kata kunci: kearifan lokal; resolusi konflik; runggu; Suku Pakpak

\section{Introduction}

Indonesia is a country that has abundant resources; there is the potential of the natural culture and the potential of the culture itself. The Indonesian culture existed long before independence in 1945 , and local wisdom spread throughout the archipelago. Every culture has a method or wisdom used for resolving conflicts (Koentjaraningrat 1993). The culture and local wisdom have succeeded at being both a glue and a solution to conflicts. Conflict cannot be eliminated from people's lives, and 
it inherent in human presence. The age of conflict is the same as humans' age; therefore, confronting and resolving conflicts is one of the extraordinary abilities of humans compared to other creatures. The affirmation is that humans have their conflict resolution systems at both the individual and communal level.

As a result, culture and human civilization's manifestation has provided its conflict resolution mechanism and that commonly called local wisdom. Conflict is a representation of the efforts to naturally defend and expand individual values and interests internally and externally in a manner that occurs at all life levels and in all life circles (Jeong 2008, Tov 2004, McCollum 2009). Humans have adapted to conflict, including forming an attitude, set of values, or a series of habits to apply as a resolution method. Although conflicts have always existed in human life, conflicts are also solvable (Wallensteen 2002). The dynamics, problems, and conflicts then become an experience, which then becomes wisdom. Every culture has policies for dealing with its problems, and it is called local wisdom (Ilyas 2014). Local wisdom is a manifestation of the community's informal norms that become a benchmark in social interaction to avoid conflict (Ruslan 2018). Therefore, local wisdom is a form of knowledge that results from a long process; it evolves in the community's environment and share (Tiezzi et al. 2003). It can be concluded that local wisdom is a combination of the intelligence, creativity, and knowledge of the community and the elite when building and maintaining the community (Hasbullah 2012).

In addition, the resolution of conflicts by the national law, which is also a concept of cultural heritage, often does not provide a solution. National law in a community can disrupt and damage the social cohesion that has existed for a long time. It is possible because the resolution of social conflicts in the perspective of national law confirms who is wrong and right. The impact of the verdict is also very pronounced in the community. It is different from the local wisdom approach to conflict resolution. The solution finds common ground and a consensus as possible to seek peace among the conflicting parties. It includes the sentences that consider the offender's social position, so then the form of punishment is not so pronounced and burdensome for both the perpetrator and victim. Therefore, local wisdom is a sound system that can be used as an alternative to conflict resolution. Sartini (2004) said that local wisdom has a unique role and function that is apparent in norms, values, and beliefs. Local wisdom that has both a place and strong acceptance in the community becomes a space and opportunity to resolve conflicts. In addition to maintaining long-established social cohesion and engagement, law enforcement agencies also provide security in the community, especially in terms of the penitentiary or Lembaga Pemasyarakatan (Lapas) capacities overflowing with the capacity to a backlog of cases. It can lead to lower quality law enforcement practices, namely selecting cases that must be resolved first.

Pakpak is one of the ethnic groups in Indonesia that still survives today. Pakpak scattered across various districts or cities in Sumatra, such as Dairi, Pakpak Bharat, Subulussalam, Aceh Singkil, and Tapanuli Tengah. Herna (2015) stated that Pakpak is almost extinct; it cannot be denied due to the colonial policy that caused the Pakpak people to experience much discrimination. Since the colonial period, Pakpak has experienced cultural disorientation, causing a loss of identity and turning to other ethnic cultures (Agustono 2011). Clan change, for example, is standard in the Pakpak community to resolve the conflict of mysticism and the identity of the Pakpak; like other tribes, Pakpak has a wealth of local wisdom. Pakpak, as a tribe, has a culture, a system, and specific rules for managing relationships both internally and externally. Pakpak has a custom that regulates marital relations, rights, obligations, restrictions, and land laws (Viner 1981). Pakpak is increasingly known to the broader community due to its division from the Pakpak Bharat Regency in 2003. As Agustono (2011) said; however, the regency's presence gave power and opportunity to the Pakpak in terms of reconstructing and revitalizing its identity. Pakpak Bharat Regency is a fraction of the Dairi Regency, one of the Pakpak tribe's original areas.

According to Suprapto (2013), there are at least six reasons for the relevance, significance, or urgency of conflict resolution through local wisdom: 1) it is a marker of the identity of a community, 2) there is the adhesive element (cohesive aspect) among the citizens and across different religions and faiths, 
3) the local wisdom is not coercive; however, rather an inner awareness, 4) local wisdom facilitates the togetherness of a community, 5) there is the ability of the local wisdom to change mindsets and create reciprocal relationships between individuals and groups and to find common ground, and 6) the local wisdom can encourage the process of appreciation and participation and minimize the factors that damage community solidarity and integration. The affirmation is that through the local wisdom approach, conflicts resolve by a win-win solution rather than a win-lose solution; therefore, the local wisdom approach is the approach that must be taken. The revitalization of Pakpak values and culture is open, along with the presence of regional autonomy. The constitutional mandate of Article 18 Paragraph (2) of the 1945 Constitution of the Republic of Indonesia states that the state recognizes and respects the customary law community units along with their traditional rights as long as they are alive and following the development of society and the principles of the state unity of the Republic of Indonesia regulated in law. LB said that Pengituai Kuta is a form of local wisdom in the Pakpak culture; it consists of older men in the Pakpak who consider having qualified capabilities, experience, and knowledge. LB added that the Pengituai Kuta, apart from resolving conflicts, can also act as traditional spokespersons, Kuta leaders, and a traditional healer.

Pengituai Kuta can be referred to in the present context as consisting of community leaders; however, unlike community leaders, Pengituai Kuta has cultural legitimacy when providing advice and making decisions on a problem or conflict in the community. The Pengituai Kuta are culturally prominent figures, while community leaders are distinct at the social level. Pengituai Kuta has a central and respected role in the Pakpak community and has the function of permitting all village activities, resolving any problems between residents and other social functions. The affirmation is that Pengituai Kuta has a high position culturally in the Pakpak community. Based on those mentioned earlier, the author is interested in examining the role of the Pengituai Kuta concerning conflict resolution. It is exciting and in line with the changing times and people's lifestyles. It is interested in researching the pattern of conflict resolution in society. What are the sources of laws and regulations used when resolving conflicts? What are some examples of the problems that have been solved? The research site's location is Matanari Hamlet, Ujung Teran Village, Dairi Regency, North Sumatera. Matanari Hamlet still maintains the Pengituai Kuta system in daily life.

\section{Research Method}

This research is a descriptive qualitative study involving a case study. The use of case studies begins with discovering cases of phenomena considered attractive to investigate or represent something new that can refute existing theories or provide alternatives to a phenomenon (Sarosa 2012). The data collection techniques used were observations and semi-structured interviews, which were then enriched and elaborated with library studies. In this research, the critical sources of information were representatives from the Pengituai Kuta and the government's representatives, namely the village head. The information subjects in this study were two people, namely one member of the Pengituai Kuta (JM, 60 years), the head of hamlet (PP, 40 years), and cultural practitioner or humanist (LB, 60 years). The data was analyzed qualitatively according to the Miles and Huberman model, including the data collection, reduction, presentation, and conclusions (Sugiyono 2015).

\section{Results and Discussion}

\section{Pengituai Kuta}

Pengituai Kuta plays an essential role in maintaining communal harmony and peace, and it functions at the center of the solution when a conflict occurs between residents. All problems that are tried and decided by the Pengituai Kuta usually end in peace (win-win solution) even if the perpetrator has to pay a fine, and it has no clear and written provisions. In Matanari, so far, the number of Pengituai Kuta is five people. It depends on the number of community leaders who are willing to be chosen. These elections usually consider the number of figures who consider being capable. They are usually chosen and confirmed by the residents through deliberations known as runggu. The head of the village, as a political representation of the government, has an important role. Any problems that 
report to the village head will be brought to the Pengituai Kuta. The village's head takes the initiative to invite the Pengituai Kuta to discuss public complaints. JM stated that:

"The village head or government's position is not lower than the Pengituai Kuta; however, the village head will usually ask the Pengituai Kuta to resolve the problem."

There is a form of respect shown by the village government (politics) towards the cultural government (Pengituai Kuta) concerning resolving community conflict. All problems in the community brought to the Pengituai Kuta except for significant cases such as murder. They usually continue to take persuasive action so then the case is not prolonged. The Pengituai Kuta can handle cases that are usually complaints in Indonesian law except if the litigants want to settle in court; however, this is the last option after the persuasion process, and the meeting conducted by the Pengituai Kuta has failed, and this is rarely done. JM said that:

"Mella Enggo I cakapi situa-situa, enggo sidung."

(If Pengituai Kuta has finished, it's usually done)

The success of Pengituai Kuta in solving problems in Matanari is due to the firm belief in Pengituai Kuta as a respected figure. It is in line with a critical person in a community group who has a significant conflict resolution role (Kondalkar 2007 in Putra 2013). In other words, the Pengituai Kuta has the power, as defined by Budiardjo (1972), to influence other people or groups according to their wishes; however, in the context of Pengituai Kuta, their desires are neither prominent nor strong because the mechanisms and decisions are carried out transparently and openly. Acceptance and respect from the society towards the community leaders are formed rather than innate. The status of a Pengituai Kuta, or a community figure, is influenced by the individual's wealth, knowledge, character, and success in life (Rembang et al. 2018). The status as Pengituai Kuta is therefore dynamic. Based on the author's instructions, there were several members of Pengituai Kuta who resigned because they felt unable to carry out their duties.

\section{Values in runggu}

During the conflict resolution process, several practiced values through runggu are equality, openness, deliberation, and restorative conflict resolution. These values appear in almost every process when resolving conflicts. Manifestations of equality are apparent as the perpetrators and victims treat equally. Both the victim and the perpetrator are allowed to explain their side of the problem. Equality also becomes apparent in the Pengituai Kuta's position, where they only mediate and facilitate. The runggu decision is still submitted to the forum and agreed upon mutually. The community also has the opportunity to provide opinions or input. Openness is apparent during the conflict resolution process. The community, especially the elderly, can witness runggu. PP said that:

"Kennah Ngo I, saksina jelma mbellang asa karina, sekaligus mersiajar."

(It must be witnessed by the wider community to know and learn at the same time)

In addition to this, JM stated that:

"This openness is in order to minimize the public suspicion or negative views of the case."

Deliberation is the primary value within the runggu process. Decisions are based on joint decisions that do not involve voting. If they do not meet the agreed point, it is better to postpone it; however, this is very rare. According to the author, the restorative approach or paradigm is an essential thing, as it is this that results in the role of the Pengituai Kuta having strong legitimacy in the community. It is restorative because the offender is not solely in a guilty position as they have the opportunity to be heard. In law, the paradigm of restorative justice emphasizes efforts to improve and reconcile the conflict. This paradigm also emphasizes the perpetrators, victims, and the community in the criminal settlement process. As a result, the role of the state becomes smaller (Azhar 2019, Muhaimin 2019). 
According to Prayitno (2012), restorative justice follows Pancasila, especially the fourth precept, which prioritizes deliberation when making decisions. Even if not wholly, restorative principles emerge during the process of runggu, starting from the community's involvement and the victims and perpetrators and the process of determining the solutions or penalties based on consensus. It reinforces the legitimacy of the community concerning the results of the decisions.

Runggu is the process of prioritized deliberation and consensus. In addition to the values of openness, equality, and restorative settlement, there are several benefits of deliberation when solving nonlitigation dispute problems namely, 1) informal, flexible and straightforward dispute resolution, 2) both parties obtain low cost, 3) victory so then friendship is maintained, and 4) the parties resolve the conflict satisfactorily, and the results are acceptable to both parties involved in the dispute (Ilyas 2018). Apart from the hereditary and cultural factors, another thing that might be a consideration for the community to keep runggu as a conflict resolution in the Matanari Hamlet is the distance from the nearest police station or the court. Matanari Hamlet is about $16 \mathrm{~km}$ away from the nearest sub-district or about 31 $\mathrm{km}$ away from the district itself. It, therefore, requires more time and money if this litigation route is chosen for conflict resolution. In this case, local wisdom becomes an alternative in the community.

\section{Conflict resolution process}

The settlement of conflicts that occur in the community is usually responded to by the Pengituai Kuta. If they know there is a problem, they immediately approach. If it has not yet met a common ground and causes more significant problems, it will be resolved by the Pengituai Kuta. The process of resolving conflicts is usually carried out at night. After coordinating with the local government or the hamlet head, an announcement is made to the residents to gather at the hamlet head's house or one of the litigants' house. The selection of night time is because the majority of the population work as farmers. By prioritizing the consensus-system, Pengituai Kuta leads the conflict mediation, called runggu. All residents who come are allowed to provide advice and suggestions. The Pengituai Kuta's function is to facilitate, mediate, and guide the runggu process. Both litigants are presented in the process.

Conflict resolution is often relatively short. The problems are resolved at the meeting time because the two parties are involved openly and face-to-face. It is easier to find the problem, so then the solution can be immediately decided. There are no written laws or norms. The legal source that becomes the reference and basis is the mutual agreement between the two parties and the community. The same problem can result in different decisions, for example, in the number of fines due. It is based on other considerations and dynamics in the runggu. The form of decision that must be carried out by the party that is considered guilty is often to pay a fine and feed the victim as an apology; however, there is also an agreement that it is enough to have a false confession and an apology without doing them. It is usually if the litigants are still close relatives. Openness, equality, and kinship are maintained as important points concerning how the Pengituai Kuta can efficiently resolve community conflicts. Every resident has the right to provide input concerning the solution of the problem. The problem is in the open and discussed collectively. The kinship that underlies the citizens, even if they are from different religions and tribes, makes conflict resolution run smoothly.

Table 1 shows problems that have been successfully resolved over the last 2-3 years by the community and the Pengituai Kuta. This data was obtained from the researcher's observations and the interviews with the respondent sources of information. There have not been any problems or conflicts in the Matanari Hamlet. Due to the relatively small community of around 80-90 families who live a relatively homogeneous life away from the crowds. In addition, not all problems are brought to the Pengituai Kuta. Some issues were resolved amicably or internally. The table below lists some of the issues resolved through runggu and the resulting decision.

Based on Table 1, it can be said that Pengituai Kuta, through the runggu culture, is relatively successful at resolving the conflicts in society. It can be imagined that if these cases were brought to court, the judicial process would take longer, and the decisions would be more complicated. The conflict resolution process through the Pengituai Kuta and runggu is much more straightforward 
without complicating substance abuse enforcement matters. The same thing said by Aedi (2019) concerning conflict resolution, mainly minor criminal offenses. It was consistent and following Article 18B Paragraph (2), which states that the state recognizes and respects units of law indigenous and tribal peoples and their traditional rights long as they were alive and following the development of society and the principle of the Unitary Republic of Indonesia, which is set in the legislation.

Table 1.

A number of cases resolved by the Pengituai Kuta

\begin{tabular}{lcc}
\hline \multicolumn{1}{c}{ Cases } & Year & Decision \\
\hline $\begin{array}{l}\text { Durian theft: A family man known to } \\
\text { steal other residents' durian for sale. }\end{array}$ & 2015 & Fine. \\
$\begin{array}{l}\text { Murder: The victim died on the spot. } \\
\begin{array}{l}\text { The culprit is imprisoned. One of the } \\
\text { victims' families had wanted revenge, }\end{array}\end{array}$ & 2016 & $\begin{array}{l}\text { The perpetrator remains in } \\
\text { prison. The two parties remain at } \\
\text { put a member of the Pengituai Kuta } \\
\text { prevented this by inviting a dialogue. }\end{array}$ \\
$\begin{array}{l}\text { Money Theft: a teenager was caught } \\
\text { stealing. }\end{array}$ & 2017 & \\
$\begin{array}{l}\text { Land Ownership Dispute: One family } \\
\text { was known to have sold the land that } \\
\text { has been used as collateral for a loan } \\
\text { from a bank. Pengituai Kuta brought } \\
\text { together the two parties, specifically } \\
\text { the seller and the prospective buyer. }\end{array}$ & 2019 & $\begin{array}{l}\text { The land buyer cancelled his } \\
\text { purchase. }\end{array}$ \\
$\begin{array}{l}\text { Source: Interviews with JM (2019) and PP (2019) combined with observations conducted by the } \\
\text { researcher. }\end{array}$
\end{tabular}

Pengituai Kuta does not the only function in conflict as previously described by LB. In traditional and celebratory activities, Pengituai Kuta must be notified in advance. Pengituai Kuta must also be notified if a family is going to have a party. It confirms the central role of the Pengituai Kuta or, in other words, the high level of public respect for them. Likewise, to deal with problems in the village, such as cooperation, it is discussed through a hallway or a meeting chaired by the Kuta chief.

The conflict resolution process through Pengituai Kuta's Pakpak can be said to be quite successful at resolving conflicts and maintaining social cohesion. According to Haba (2008), there are five essential roles of local wisdom as conflict resolution. First, local wisdom is part of the identity and characteristics of the community itself. Second, every form of local wisdom has cohesive aspects in an adhesive element between the different religions, citizens, and beliefs. The third is that the law on the concept of local wisdom is by consensus different from the positive law that seems "forced." Fourth, local wisdom emphasizes the importance of togetherness within a community, and it functions to encourage the development of togetherness and appreciation and a sharing mechanism. It then prevents the possibility of polarization or the disintegration of the community. Fifth, local wisdom emphasizes and places the culture owned above both individuals' and groups' interests. Local wisdom is of importance in the Indonesian culture. Local wisdom is a particular asset owned by Indonesians. In other words, local wisdom or culture is a state asset (Ode 2015). Therefore utilizing the local wisdom when resolving conflicts or problems in a horizontal society is a necessity. It is even more vital because the local wisdom is believed and accepted by the community, which then survives and becomes known as tradition (Hasbullah 2012).

Local wisdom is valued and the habits and customs in which there is wisdom (Wahyudi 2018). Local wisdom is a product of people's daily lives in a community that then crystallizes and the community members' life needs. Local wisdom is created based on the experience and habits of particular communities. It becomes something that is considered wise or following the community. Culture or local wisdom can be used to help the country create a peaceful atmosphere in society. The acceptance or legitimacy of healthy local wisdom makes it more effective. The legitimacy of local wisdom is healthy because it is rooted and considered sacred. It is readily accepted by the community, 
so its implementation can be more efficient and effective (Astri 2011). It is necessary and essential to prioritize the wisdom of the community when resolving conflicts. Conflict resolution using local wisdom has a constitutional and juridical basis in Indonesia. It is stated in Article 18 Paragraph (2) of the 1945 Constitution of the Republic of Indonesia and the issuance of the Law on Regional Government. It was so then conflict resolution using local wisdom is the basis of conflict resolution, and so then it does not conflict with Pancasila (Taufiq et al. 2016). In addition, conflict resolution using the local wisdom approach is more effective, especially in terms of horizontal conflicts because the local wisdom is rooted in people's lives (Asnawi 2016). The same thing was stated by Kasim and Nurdin (2016) in that local wisdom has two impacts: conflict resolution in the community and a better impact than formal justice.

\section{Conclusion}

Conflict resolution through a local wisdom approach is beneficial and efficient at enforcing the law while maintaining horizontal harmony in society. Local wisdom has legitimacy because it has become a habit, culture, and belief in the community in daily life. The Pengituai Kuta system in the Pakpak culture is one form of local wisdom that effectively resolves community conflicts. Through the mechanism of deliberation or consensus, known by the term runggu, Pengituai Kuta looks for a solution to every problem or conflict in the community. All citizens have an equal opportunity and position when providing opinions, input, and solutions to conflicts. Pengituai is a mediator, facilitator, and decision-maker for the punishment for those considered guilty. Local and even national governments need to develop and re-cultivate local wisdom approaches when resolving community conflicts. It becomes an alternative when the legal system does not work well or is not in line with community expectations.

\section{References}

Aedi AU (2019) Penyelesaian tindak pidana ringan melalui kearifan lokal dalam pembangunan sistem hukum nasional. Jurnal Rechtsvinding: Media Pembinaan Hukum Nasional 8 (1):113-126. https://doi.org/10.33331/rechtsvinding.v8i1.307.

Agustono B (2011) Rekonstruksi identitas etnik: Sejarah sosial politik Orang Pakpak di Sumatera Utara 1958-2003. Jurnal Masyarakat Indonesia 37 (1):165-184.

Asnawi MH (2016) Resolusi konflik berbasis nilai-nilai kearifan lokal: Penggalian sejarah dan budaya lokal dalam rangka meneguhkan multikulturalisme dan toleransi budaya. Jurnal Keguruan dan Ilmu Pendidikan 3 (2):198-203.

Astri H (2011) Penyelesaian konflik sosial melalui penguatan kearifan lokal. Aspirasi 2 (2):151-162.

Azhar AF (2019) Penerapan konsep keadilan restoratif (restorative justice) dalam sistem peradilan pidana di Indonesia. Mahkamah: Jurnal Kajian Hukum Islam 4 (2):134-143.

Budiardjo M (1972) Dasar-Dasar Ilmu Politik. Jakarta: Gramedia Pustaka.

Haba J (2008) Revitalisasi Kearifan Lokal: Studi Resolusi Konflik di Kalimantan Barat, Maluku dan Poso. In: Abdullah I et al. (eds). Agama dan Kearifan Lokal dalam Tantangan Global. Yogyakarta: Pustaka Pelajar.

Hasbullah (2012) Rewang: Kearifan lokal dalam membangun solidaritas dan integrasi sosial masyarakat di Desa Bukit Batu Kabupaten Bengkalis. Jurnal Sosial Budaya 9 (2):231-243.

Herna H (2015) Kebudayaan masyarakat Kabupaten Pak-Pak Barat. Jurnal Bahas Unimed 26 (3):375-379.

Ilyas I (2014) Kajian penyelesaian konflik antar desa berbasis kearifan lokal di Kabupaten Sigi, Sulawesi Tengah. Academica 6 (1):1213-1227.

Ilyas M (2018) Tinjauan Hukum Islam terhadap musyawarah dalam penyelesaian sengketa ekonomi. Jurnal Al-Qadau 5 (2): 227-236. https://doi.org/10.24252/al-qadau.v5i2.7104.

Jeong HW (2008) Understanding Conflict and Conflict Analysis. Los Angeles: SAGE. 
Kasim FM \& Nurdin A (2016) Resolusi konflik berbasis kearifan lokal di Aceh: Studi tentang eksistensi dan peran lembaga adat dalam membangun perdamaian di Kota Lhokseumawe. Ilmu Ushuluddin 3 (1):101-118.

Koentjaraningrat RM (1993) Manusia dan Kebudayaan di Indonesia. Jakarta: Penerbit Djambatan.

McCollum S (2009) Managing Conflict Resolution. New York: Chelsea House.

Muhaimin (2019) Restoratif justice dalam penyelesaian tindak pidana ringan. Jurnal Penelitian Hukum De Jure 19 (2):185-206. https://doi.org/10.30641/dejure.2019.V19.185-206.

Ode S (2015) Budaya lokal sebagai media resolusi dan pengendalian konflik di Provinsi Maluku (Kajian,tantangan dan revitalisasi budaya pela). Politika 6 (2):93-100.

Prayitno KP (2012) Restoractive justice untuk peradilan di Indonesia (Perspektif yuridis filosofis dalam penegakan hukum in concreto). Jurnal Dinamika Hukum 12 (3):407-420. http://doi. org/10.20884/1.jdh.2012.12.3.116.

Putra MGBA (2013) Peran kearifan lokal dalam resolusi konflik keyakinan beragama di Jawa Timur. Masyarakat, Kebudayaan dan Politik 26 (1):1-14.

Rembang P, Lasut JJ, \& Kandowangko N (2018) Peranan tokoh masyarakat dalam penanganan masalah sengketa tanah di Desa Sulu Kecamatan Tatapaan Kabupaten Minahasa Selatan. Holistik 10 (21A):1-18.

Ruslan I (2018) Dimensi kearifan lokal Masyarakat Lampung sebagai media resolusi konflik. Kalam 12 (1):105-126. https://doi.org/10.24042/klm.v12i1.2347.

Sarosa S (2012) Penelitian Kualitatif Dasar-Dasar. Jakarta: PT Indeks.

Sartini (2004) Menggali kearifan lokal nusantara sebuah kajian filsafati. Jurnal Filsafat 37 (2):111-120.

Sugiyono (2015) Metode Penelitian Kualitatif, Kuantitatif, dan R\&D. Bandung: Alfabeta.

Suprapto (2013) Revitalisasi nilai-nilai kearifan lokal bagi upaya resolusi konflik. Walisongo: Jurnal Penelitian Sosial Keagamaan 21 (1):19-38.

Taufiq M, Sarsiti, \& Rindha W (2016) Forms and mechanisms of law dispute resolution using the principle of Pancasila based on local wisdom. Dinamika Hukum 16 (1):24-30. http://doi. org/10.20884/1.jdh.2016.16.1.399.

Tiezzi EN, Marchettini, \& Rosini M (2003) Extending the environmental wisdom beyond the local scenario: Eco-dynamic analysis and the learning community. Transactions on Ecology and the Environment 63:349-356.

Tov YB (ed) (2004) From Conflict Resolution to Reconciliation. New York: Oxford University Press.

Viner AC (1981) Pakpak adat and kinship terminology: An assessment of their meaning an mutual relationship. Anthropologica 23:145-165.

Wahyudi B (2018) Penanganan Konflik: Pendekatan Kearifan Lokal. Yogyakarta: Pustaka Senja.

Wallensteen P (2002) Understanding Conflict Resolution: War, Peace and the Global System. London: SAGE. 